\title{
Genetic Stock Identification and Relative Contribution of Arctic Char (Salvelinus alpinus) from the Hornaday and Brock Rivers to Subsistence Fisheries in Darnley Bay, Northwest Territories
}

\author{
Les N. Harris, ${ }^{1,2}$ David A. Boguski, ${ }^{1,3}$ Colin P. Gallagher ${ }^{1}$ and Kimberly L. Howland ${ }^{1}$
}

(Received 25 November 2015; accepted in revised form 31 March 2016)

\begin{abstract}
Where anadromous fishes occur in the Canadian Arctic, they provide the mainstay of local subsistence fisheries of varying intensities. Many of these fisheries harvest a mixture of stocks at discrete locations and it is often not known which stocks, specifically, are being harvested and to what extent. In the Darnley Bay area of the Northwest Territories, Arctic char, Salvelinus alpinus, in particular have long provided an important subsistence resource to residents of Paulatuk, and char from two systems (the Hornaday and Brock Rivers) are thought to contribute to the coastal fishery for this species. Genetic mixed-stock analysis (GMA) is routinely applied for resolving stock contributions to such fisheries, yet studies incorporating GMA to understand specifically which stocks are being harvested in the Canadian Arctic, and to what extent, are relatively scarce. In this study, we assayed microsatellite DNA variation among 987 Arctic char from two important coastal subsistence fisheries and several inland sampling locations in the Darnley Bay area to (1) assess the degree of genetic structuring between the Hornaday and Brock Rivers and (2) resolve the proportional contributions of these stocks to coastal mixed-stock fisheries in the region using GMA. Overall, genetic differentiation was relatively high and significant $(\theta=0.117 ; 95 \%$ C.I. $=0.097-0.142)$ among baseline sampling locations. Overall patterns of genetic stock structure also support previous hypotheses that additional life history types (e.g., landlocked or freshwater-resident char, or both) exist in the Hornaday system, as indicated by elevated levels of genetic differentiation between some of our sampling locations. The GMA suggested that, while both river systems contribute to the coastal fishery, catches were dominated by Arctic char from the Hornaday River, which highlights the importance of this system. All told, our results may be relevant to the management of the subsistence fishery in Darnley Bay and for furthering the collective understanding of char biodiversity and life history variation in the Canadian Arctic.
\end{abstract}

Key words: Arctic char; Salvelinus alpinus; mixed-stock fishery; genetic mixed-stock analysis; subsistence harvest; Darnley Bay

RÉSUMÉ. Dans les milieux de l'Arctique canadien où l'on trouve des poissons anadromes, ceux-ci sont à la base de pêcheries de subsistance locales d'intensités variées. Grand nombre de ces pêcheries permettent de récolter un mélange de stocks à différents endroits et nous ne savons souvent pas quels stocks en particulier sont récoltés et jusqu’à quel point. Dans la région de la baie Darnley, dans les Territoires du Nord-Ouest, l'omble chevalier, Salvelinus alpinus, en particulier, a longtemps fourni une ressource de subsistance importante aux résidents de Paulatuk, et des ombles de deux réseaux (les rivières Hornaday et Brock) semblent contribuer à la pêche de cette espèce en eaux côtières. La méthode de l'analyse génétique de stocks mélangés est souvent employée pour déterminer les contributions de différents stocks à ce genre de pêcheries, mais relativement peu d'études intégrant l'analyse génétique de stocks mélangés ont été réalisées pour comprendre exactement quels stocks sont récoltés dans l'Arctique canadien, et jusqu’à quel point. Dans cette étude, nous avons analysé des variations d'ADN microsatellite chez 987 ombles chevaliers de deux importantes pêcheries de subsistance côtières et plusieurs sites d'échantillonnage intérieurs dans la région de la baie Darnley pour 1) évaluer le degré de structuration génétique entre les rivières Hornaday et Brock et 2) déterminer les contributions proportionnelles de ces stocks par rapport aux pêches côtières de stocks mélangés dans la région au moyen de l'analyse génétique de stocks mélangés. Dans l'ensemble, la différenciation génétique était relativement élevée et significative $(\theta=0,117$; IC à $95 \%=0,097-0,142)$ parmi les sites d'échantillonnage de base. Les tendances générales relatives à la structure génétique des stocks appuient également des hypothèses antérieures selon lesquelles d'autres types de cycles de vie (p. ex. l'omble confiné aux eaux intérieures ou l'omble d'eau douce, ou les deux) existent dans le réseau Hornaday, tel qu'indiqué par les niveaux élevés de différenciation génétique entre certains de nos sites d'échantillonnage. L'analyse génétique des stocks mélangés suggère que, bien que les réseaux des deux rivières contribuent à la pêche côtière, l'omble chevalier de la rivière Hornaday dominait les prises, ce qui met en évidence l'importance de ce réseau. Dans l'ensemble, nos résultats peuvent être pertinents pour la gestion de la pêche de subsistance dans la baie Darnley et pour favoriser la compréhension collective de la biodiversité de l'omble et de la variation de son cycle vital dans l'Arctique canadien.

\footnotetext{
${ }^{1}$ Fisheries and Oceans Canada, 501 University Crescent, Winnipeg, Manitoba R3T 2N6, Canada

${ }^{2}$ Corresponding author: Les.N.Harris@dfo-mpo.gc.ca

${ }^{3}$ Biodive Scientific Inc., 43 Casselman Crescent, Oak Bluff, Manitoba R4G 0A2, Canada

(C) Her Majesty the Queen in Right of Canada. Administered by the Arctic Institute of North America
} 
Mots clés : omble chevalier; Salvelinus alpinus; pêche de stocks mélangés; analyse génétique de stocks mélangés; prise de subsistance; baie Darnley

Traduit pour la revue Arctic par Nicole Giguère.

\section{INTRODUCTION}

Subsistence and commercial fisheries exist throughout the Arctic and have played vital roles in sustaining the traditional Inuit way of life, while also presenting employment opportunities within the local economies of northern communities (Kristofferson and Berkes, 2005; Roux et al., 2011a). Subsistence fisheries, in particular, have been important for sustaining Inuit for millennia and have helped shape the contemporary distribution of northern and Arctic communities (Friesen, 2002, 2004). These fisheries often target anadromous fishes within marine environments or during their downstream or upstream migrations between fresh and marine waters (Kristofferson and Berkes, 2005; Roux et al., 2011a). These migrations often result in the mixing of discrete fish stocks during summer feeding in marine habitats or during migrations to and from marine environments. Such mixed-stock fisheries can severely complicate fisheries management when it is not known which stocks are being harvested and to what extent (Utter and Ryman, 1993; Bradbury et al., 2016). This is almost always the case for Arctic subsistence fisheries that target anadromous stocks in marine environments. Further complicating the management of these fisheries is the potential for temporal variation in the proportional contribution of discrete stocks to the harvest. Therefore, understanding which stocks are being harvested in these mixed-stock fisheries and their annual harvest levels has become an important objective for many fisheries managers (Krueger et al., 1999; Flannery et al., 2010; Bradbury et al., 2016).

Arctic char (Salvelinus alpinus), in particular, have long been an important northern subsistence food source throughout their range and are widely considered one of the most important fish resources in the Canadian Arctic (Priest and Usher, 2004; Roux et al., 2011a; Zeller et al., 2011). The Darnley Bay region of the Northwest Territories, Canada, currently supports a sustainable Arctic char subsistence fishery for the community of Paulatuk (PHTC, 1999; Harwood, 2009). From 1968 to 1986, a commercial fishery for Arctic char existed in the region, and several annual quotas, ranging from $2300 \mathrm{~kg}$ to $6800 \mathrm{~kg}$, were implemented (Kristofferson et al., 1989). A decline in catch rates in the early 1980s resulted in the closure of the commercial fishery in 1987 (Harwood, 2009). Still pervasive in the region, however, is subsistence fishing, the management of which follows guidelines highlighted in the Paulatuk Charr Management Plan (PHTC, 1999). Between 2003 and 2013, the total coastal harvest of Arctic char in Darnley Bay ranged from 479 (in 2008) to 1793 (in 2009), the majority of which were harvested in the Hornaday River Delta and surrounding area (DFO, unpubl. data). Arctic char are harvested primarily by gill nets at different locations and times of the year, in riverine and marine environments (Harwood, 2009; Harwood and Babaluk, 2014). Late spring and summer fisheries take place in coastal areas near the community where two potential Arctic char stocks mix. These include Arctic char from the Hornaday River, which enters Darnley Bay $16 \mathrm{~km}$ east of Paulatuk, and Arctic char from the Brock River which enters Darnley Bay $\sim 40 \mathrm{~km}$ to the east of the community (see Fig. 1). Given that these are the only two known Arctic char-bearing river systems that drain to Darnley Bay, it is probable that the coastal fisheries in the region are composed of mainly fish originating from these two rivers. Further, the relative contributions of Arctic char from these two rivers to the coastal fisheries likely vary by fishing location and between years. Additionally, landlocked Arctic char that have no access to marine environments and freshwater residents that have access to marine environments, but do not undertake anadromous migrations, have been confirmed in these two river systems (Babaluk et al., 1998; Roux et al., 2011b), and traditional knowledge holders have recognized the existence of additional life history variation in the region for generations (Noel Green, Paulatuk resident, pers. comm. 2016). Accordingly, the coastal and inland fisheries near the community of Paulatuk, which include Hornaday and Brock Rivers proper and freshwater lakes within these drainages, present opportunities to study a potential mixed-stock fishery and to discern and document additional life history variation (i.e., anadromous vs. resident vs. landlocked life histories) among Arctic char distributed within the Darnley Bay region. Currently, nothing is known about the relative proportions of discrete Arctic char stocks within Darnley Bay and their contribution to coastal fisheries. Furthermore, knowledge about life history variation among Arctic char in this region will add to our collective understanding of biodiversity in Canada's Arctic.

Mixed-stock analysis (MSA) is a modeling procedure that estimates the relative contributions of potential donor stocks to a mixture of fish that are being harvested (Utter and Ryman, 1993). Fisheries managers use this method extensively to estimate the proportional contribution of stocks to mixed-stock fisheries. This is especially true on the west coast of North America, where mixed-stock analysis has been routinely used for decades on all Pacific salmon species (Seeb and Crane, 1999; Habicht et al., 2010; Beacham et al., 2011, 2012; Small et al., 2015). Assessments of the utility of MSA in Canadian Arctic fisheries are only recently emerging (but see Harris and Taylor, 2010). Several techniques have been used in MSA, including physical 


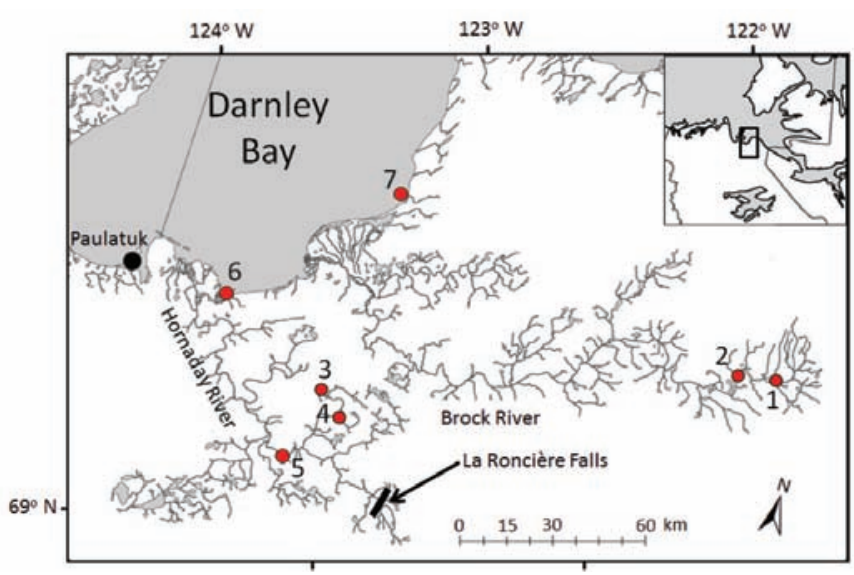

FIG. 1. Map showing sampling locations for anadromous and landlocked Arctic char of the Darnley Bay region of the Northwest Territories. The inset map shows the location of Darnley Bay in Canada. For key to sampling location codes, see Table 1.

tagging (e.g., Gilbert, 1924) and identification through scale patterns (e.g., Cook and Guthrie, 1987) and parasites (e.g., Margolis, 1963). In recent years, however, genetic methods, that is, genetic stock identification (GSI) and subsequent genetic mixture analyses (GMA), have become commonplace. Mixture analysis incorporating GSI differs computationally from traditional genetic assignment tests, which assign an individual to one potential contributing stock on the basis of its multilocus genotype. GMA, on the other hand, does not assign individual fish per se, but rather estimates the proportional contribution of source genotypes ("baseline" stocks potentially contributing to a fishery) to the mixed-stock fishery (Manel et al., 2005). These fractional proportions are allocated to the corresponding baseline sampling locations, and the overall mixture proportions are estimated as the sum of all fractional assignments. This method is thought to be more accurate than traditional assignment tests (e.g., Hedgecock et al., 2001) and provides a powerful tool for resolving proportional contributions to mixed-stock fisheries, especially when coupled with genetic markers that resolve fine-scale patterns of genetic stock structure (e.g., Ruzzante et al., 2000; Harris and Taylor, 2010; Beacham et al., 2012; Small et al., 2015).

This study aimed to better our understanding of contributions of Hornaday River and Brock River Arctic char to coastal, mixed-stock fisheries near the community of Paulatuk and to collect information that could be incorporated into the Paulatuk Charr Management Plan. Its specific objectives were to (1) describe patterns of genetic variation and the degree of differentiation between the Hornaday and Brock River systems through assessments of microsatellite DNA; (2) identify potential life history variants (e.g., anadromous, freshwater-resident, and landlocked) that best explain patterns of genetic variation among stocks within the Darnley Bay region; and (3) resolve appropriate anadromous baselines (individuals from discrete stocks contributing to the Darnley Bay coastal fishery) using GSI methods and subsequently apply GMA to estimate the relative annual contribution of discrete Arctic char stocks to these fisheries. It is the first assessment of genetic variation and genetic stock structure of Arctic char in this region of the Canadian Arctic. The ensuing GMA of Arctic char in Darnley Bay will be important for monitoring future change within this fishery and for managing the fishery to ensure its sustainability.

\section{MATERIALS AND METHODS}

\section{Study Area}

Our study focused on the watersheds of the Hornaday and Brock Rivers and the coastal areas of Darnley Bay, Northwest Territories, where coastal fishing for Arctic char takes place near the confluence of the Hornaday and Brock River systems (Fig. 1). It is from within these two river systems - where spawning and overwintering occur-that anadromous stocks of Arctic char contribute to the coastal fisheries (Harwood and Babaluk, 2014). The headwaters of the Hornaday River are located south of Bluenose Lake in the western Kitikmeot Region of Nunavut. The more than $300 \mathrm{~km}$ of meandering river travels westward along the southern border of the Melville Hills before entering the Northwest Territories, where it subsequently turns to the northwest, entering Darnley Bay approximately $16 \mathrm{~km}$ from the community of Paulatuk. Anadromous, landlocked, and freshwater-resident forms occur in the Hornaday River system (MacDonell, 1996, 1997; Reist et al., 1997; Babaluk et al., 1998); however, the genetic relationship between these life history types has never been examined. The headwater lake of the Brock River (i.e., Brock Lake) is located in the Melville Hills region of Tuktut Nogait National Park. The length of the Brock River from the main outlet of Brock Lake to its mouth in Darnley Bay is approximately $100 \mathrm{~km}$. Brock Lake is known to support unexploited stocks of freshwater-resident and anadromous Arctic char, and the latter have been documented to travel as far as the mouth of the Hornaday River (Roux et al., 2011b).

\section{Sample Collection and Molecular Analyses}

Samples of Arctic char assayed in this study were collected from two coastal subsistence fishing locations (the mouths of the Hornaday River and Lasard Creek in Darnley Bay) between 2009 and 2012 and from two corresponding inland locations where Arctic char were sampled in lakes near the community of Paulatuk, in the Hornaday River system in 1986 and 2011 and the Brock River system in 2011 (Table 1; Fig. 1). Coastal fishery samples were collected in July and August of each year as part of a community-based subsistence fishery monitoring program (Harwood, 2009). Inland samples consisted of juvenile (pre-smolt $<150 \mathrm{~mm}$ ) char that were presumed to be anadromous. They were collected via electro-fishing from the headwater lake of the Brock River (locally known as Brock Lake, Roux et al., 
TABLE 1. Sampling locations and sample sizes for Arctic char collected from the Darnley Bay region of the Northwest Territories. Also shown are the collection year, the sample code used throughout the paper, and the data type (as it pertains to the mixed-stock fishery analysis). For the coastal "mixture" samples, the number of Arctic char harvested at each coastal location for each year in the study is also shown. Map numbers refer to Figure 1.

\begin{tabular}{|c|c|c|c|c|c|c|c|c|}
\hline Sample location & Description & Sample code & Year collected & $\mathrm{N}$ & Latitude & Longitude & Map number & Data type \\
\hline \multirow[t]{2}{*}{ Brock River system } & \multirow[t]{2}{*}{ Brock Lake } & BRK-A & 2010 & 40 & $69^{\circ} 27^{\prime} 14^{\prime \prime}$ & $121^{\circ} 40^{\prime} 58^{\prime \prime}$ & 1 & Baseline \\
\hline & & BRK-B & 2010 & 30 & $69^{\circ} 27^{\prime} 56^{\prime \prime}$ & $121^{\circ} 32^{\prime} 15^{\prime \prime}$ & 2 & Baseline \\
\hline \multirow[t]{4}{*}{ Hornaday River system } & Unnamed Lake A & LAKE-A & 2010 & 53 & $69^{\circ} 15^{\prime} 53^{\prime \prime}$ & $123^{\circ} 13^{\prime} 05^{\prime \prime}$ & 3 & Landlocked \\
\hline & Unnamed Lake B & LAKE-B & 2010 & 52 & $69^{\circ} 14^{\prime} 09^{\prime \prime}$ & $123^{\circ} 06^{\prime} 55^{\prime \prime}$ & 4 & Landlocked \\
\hline & \multirow[t]{2}{*}{ Hornaday River proper } & HORN-A ${ }^{1}$ & 1986 & 30 & $69^{\circ} 10^{\prime} 31^{\prime \prime}$ & $123^{\circ} 11^{\prime} 28^{\prime \prime}$ & 5 & Baseline \\
\hline & & HORN B ${ }^{1}$ & 2011 & 50 & $69^{\circ} 10^{\prime} 31^{\prime \prime}$ & $123^{\circ} 11^{\prime} 28^{\prime \prime}$ & 6 & Baseline \\
\hline \multirow[t]{3}{*}{ Brock coastal area } & \multirow[t]{3}{*}{ Mouth of Lasard Creek } & LAS-10 & 2010 & 22 & $69^{\circ} 33^{\prime} 22^{\prime \prime}$ & $123^{\circ} 07^{\prime} 46^{\prime \prime}$ & 7 & Mixture (762) \\
\hline & & LAS-11 & 2011 & 287 & $69^{\circ} 33^{\prime} 22^{\prime \prime}$ & $123^{\circ} 07^{\prime} 46^{\prime \prime}$ & 7 & Mixture (440) \\
\hline & & LAS-12 & 2012 & 95 & $69^{\circ} 33^{\prime} 22^{\prime \prime}$ & $123^{\circ} 07^{\prime} 46^{\prime \prime}$ & 7 & Mixture (350) \\
\hline \multirow{4}{*}{ Hornaday coastal area } & \multirow{4}{*}{ Mouth of Hornaday River } & HORN-09 & 2009 & 24 & $69^{\circ} 22^{\prime} 57^{\prime \prime}$ & $123^{\circ} 50^{\prime} 29^{\prime \prime}$ & 8 & Mixture (981) \\
\hline & & HORN-10 & 2010 & 59 & $69^{\circ} 22^{\prime} 57^{\prime \prime}$ & $123^{\circ} 50^{\prime} 29^{\prime \prime}$ & 8 & Mixture (729) \\
\hline & & HORN-11 & 2011 & 89 & $69^{\circ} 22^{\prime} 57^{\prime \prime}$ & $123^{\circ} 50^{\prime} 29^{\prime \prime}$ & 8 & Mixture (706) \\
\hline & & HORN-12 & 2012 & 156 & $69^{\circ} 22^{\prime} 57^{\prime \prime}$ & $123^{\circ} 50^{\prime} 29^{\prime \prime}$ & 8 & Mixture (816) \\
\hline
\end{tabular}

${ }^{1}$ HORN-A and HORN-B baseline samples were combined for mixed-stock fishery analysis (see Methods).

2011b) and from two lakes in the Hornaday River system. In the Hornaday River system, although we attempted to collect juvenile char via electro-fishing from several different lakes (e.g., Seven Islands Lake, Rummy Lake, and the lakes draining George, First, and Second Creeks), we were successful only in two unnamed lakes that drain a creek to the stretch on the Hornaday River known as the Coalmine-Akluk reach (Harwood and Babaluk, 2014). Hereafter, these lakes are referred to as LAKE-A and LAKE$\mathrm{B}$ (Table 1). Electro-fishing was not practical on the main stem of the Hornaday River given the size and depth of the river and the gradient of the banks. Juvenile char were targeted because they are highly unlikely to be strays, as might be expected from anadromous adults (Moore et al., 2013; Harris et al., 2014). When possible, we collected juveniles from multiple locations within the lake or from streams. However, in the Hornaday River proper, where we were unable to collect juveniles, it was necessary to use adult Arctic char as baseline samples under the assumption that they were homing to natal habitats for spawning or overwintering, and not strays from another river system that were overwintering in the Hornaday (see Moore et al., 2013). Therefore, we included archived samples of Hornaday River adult Arctic char collected in 1986 and more recent samples collected in 2011, the latter of which were provided by subsistence harvesters from Paulatuk. Adult samples from the Hornaday River consisted primarily of mature fish $(1986=23$ resting and 15 current year spawners; $2011=$ all current-year non-spawners) although some immature fish were also included $(1986=11)$. Coastal samples (collected from the subsistence fishery) were currentyear non-spawners collected annually from sites near the Brock (at Lasard Creek: LAS-10, LAS-11 and LAS-12) and Hornaday estuaries (HORN-09, HORN-10, HORN-11 and HORN-12, Table 1). We preserved fin clips or muscle tissue in $95 \%$ ethanol prior to DNA extraction using Qiagen DNeasy tissue extraction kits (Qiagen Inc., Valencia, CA) following manufacturer protocols.
Individual Arctic char genotypes were obtained at 18 microsatellite loci combined in four multiplex reactions (online Appendix 1: Table S1). For each locus, the forward primer was labeled with a fluorescent dye, and the reverse primer was PIG-tailed to reduce stutter and facilitate genotyping (Brownstein et al., 1996). Each polymerase chain reaction (PCR) was performed in a $10 \mu \mathrm{L}$ volume with $1 \mu \mathrm{L}$ of genomic DNA. The PCR cycle was as follows: an initial denaturation step of 5 minutes at $95^{\circ} \mathrm{C} ; 35$ cycles of denaturation $\left(30\right.$ seconds at $\left.94^{\circ} \mathrm{C}\right)$, annealing $\left(30\right.$ seconds at $\left.55^{\circ} \mathrm{C}\right)$, and extension ( 45 seconds at $72^{\circ} \mathrm{C}$ ); and a final extension cycle $\left(30\right.$ minutes at $\left.72^{\circ} \mathrm{C}\right)$. Amplified microsatellite fragments were analyzed using an automated sequencer (ABI 3130xl Genetic Analyzer; Applied Biosystems, Foster City, CA) with the LIZ 600 size standard. All genotypes were scored using GeneMapper software (ver. 4.0, Applied Biosystems) and then manually inspected to ensure accuracy.

\section{Genetic Data Analysis}

For each sampling location and year, MICROCHECKER (ver. 2.2.0.3; van Oosterhout et al., 2004) was used to test for genotyping errors in the form of allele scoring inaccuracies, null alleles, and large allele dropout. Basic descriptive statistics of microsatellite variation, including number of alleles $\left(\mathrm{N}_{\mathrm{A}}\right)$, expected heterozygosity $\left(\mathrm{H}_{\mathrm{E}}\right.$, Nei's unbiased gene diversity), and the inbreeding coefficient $\left(\mathrm{F}_{\mathrm{IS}}\right)$, were calculated using FSTAT (ver. 2.9.3; Goudet, 2002), while observed heterozygosity $\left(\mathrm{H}_{\mathrm{O}}\right)$ was calculated using GENEPOP. The program HP-RARE (ver. 1.1; Kalinowski, 2005) was used to calculate allelic richness $\left(A_{r}\right)$ and private allelic richness $\left(\mathrm{PA}_{\mathrm{r}}\right)$ for each sampling location, providing information on genetic variation independent of sample size. Global tests for deviations from Hardy-Weinberg equilibrium (HWE) were performed using GENEPOP (ver. 4.2; Rousset, 2008) for each sampling location and each locus, using Fisher's method to summarize multiple tests. 
GENEPOP was also used to test for genotypic linkage disequilibrium for all combinations of locus pairs within sampling locations. The results from all tests were compared with an adjusted alpha $(\alpha=0.05)$ following the False Discovery Rate (FDR) procedure (Narum, 2006).

Given that some of our samples consisted of juvenile individuals collected in presumed freshwater rearing habitats, we conducted sibship analyses to assess the potential collection of related individuals (e.g., full-sibs), which could bias our results (a phenomenon known as the AllendorfPhelps effect; Waples, 1998). To do so, we used the software COLONY (ver. 2.0; Wang and Santure, 2009) to identify likely siblings on the basis of their multilocus genotypes. For this analysis, we incorporated a microsatellite scoring error rate of $2 \%$ and assumed male and female polygamy with the potential for inbreeding. Medium-length runs and medium-likelihood precision were employed. When full-sibs were identified (i.e., "BestML" full-sibs only), we removed all but one randomly selected sibling. This resultant data set was used for all subsequent analyses.

Genetic differentiation among putative baseline sampling locations was assessed in several ways. First, log-likelihood (G)-based exact tests (Goudet et al., 1996) were used to test for genetic differentiation among baseline sampling locations over all loci combined, using default values in GENEPOP. Next, differentiation was assessed by calculating Wright's fixation index $\left(\mathrm{F}_{\mathrm{ST}}\right)$. Global $\mathrm{F}_{\mathrm{ST}}$ (theta $(\theta)$, Weir and Cockerham, 1984) was first generated in FSTAT, and the $95 \%$ CIs of the estimates were calculated using a bootstrap procedure following 10000 permutations. Next, we calculated pairwise differentiation $(\theta)$ among baseline sampling locations using the program ARLEQUIN (ver. 3.5; Excoffier et al., 2005), with the significance of the estimates determined using 10000 permutations.

Genetic stock structure was then visualized in two ways, since various approaches may lead to different conclusions regarding contemporary genetic structure (e.g., Waples and Gaggiotti, 2006; Frantz et al., 2009). First, we used Jombart's discriminant analysis of principal components (DAPC; Jombart et al., 2010) in the R (ver. 2.12.1; R Development Core Team, 2010) package adegenet (Jombart, 2008) to evaluate levels of support for different numbers of potential distinct genetic clusters in the absence of a priori population designations. This multivariate approach first uses the find.clusters function (a sequential k-means clustering algorithm) on data that have been transformed using principal component analyses (PCA). The Bayesian Information Criterion (BIC) is then used to infer the most likely number of clusters (i.e., $\mathrm{K}$ with the lowest BIC value is ideally the optimal number of genetic clusters). We visually examined $\mathrm{BIC}$ values to identify values for the number of genetic clusters $(\mathrm{K})$ beyond which BIC values decreased only subtly, as suggested by Jombart et al. (2010). We then used DAPC to perform a discriminant analysis on the retained principal components. Both DAPC analyses retained 100 principal components (PCs) that accounted for over $95 \%$ of the total genetic information as predictors for discriminant analysis (DA).
Next, we attempted to identify clusters of genetically related individuals across our study area using the Bayesian clustering method implemented in STRUCTURE (ver. 2.3.1; Pritchard et al., 2000), which also does not require a priori delineation of genetic clusters. STRUCTURE attempts to cluster individuals by minimizing Hardy-Weinberg and gametic disequilibrium (Pritchard et al., 2000), but may fail to resolve complex patterns of structuring such as isolation by distance (Jombart et al., 2010) and hierarchical genetic structure (Evanno et al., 2005). Ten independent STRUCTURE runs were executed for each of $\mathrm{K}=$ 1-10 based on the admixture model with correlated allele frequencies, using a burn-in and Markov Chain Monte Carlo (MCMC) of 250000 replicates each. The most likely number of clusters, given our multilocus genetic data, was determined by examining the estimated log probability of the data $(\mathrm{LnP}[\mathrm{D}])$ and the second order rate of change in $\log$ probability between successive $\mathrm{K}$ values (Evanno et al., 2005). To process the output, we first used STRUCTURE HARVESTER (ver. 0.6.91; Earl and vonHoldt, 2012) and then CLUMPP (ver. 1.1; Jakobsson and Rosenberg, 2007), using 1000 permutations under the LargeKGreedy algorithm, to assess the best alignment of replicate runs. Finally, we used the program DISTRUCT (ver. 1.1; Rosenberg, 2004) to visualize the admixture plots based on the best alignment.

Before performing GMA to estimate proportional contributions of Hornaday and Brock River Arctic char to the Darnley Bay subsistence fishery, we used a series of assignment tests to refine our baseline and coastal fishery samples. The accuracy of GMA and the estimation of common genetic parameters will suffer if unsampled ("ghost") baseline stocks exist that have not been included in the analyses (Beerli, 2004; Waples and Gaggiotti, 2006). Such omissions may lead to erroneous conclusions regarding contributions to harvest and subsequently hinder effective management. Given the geography of the region and the proximity of the next known Arctic char-bearing rivers (Horton River, approximately $340 \mathrm{~km}$ west of Paulatuk and the Coppermine River, about $630 \mathrm{~km}$ east of Paulatuk), it is most likely that the majority of Arctic char harvested in Darnley Bay coastal fisheries do originate from the Hornaday and Brock Rivers. However, to assess whether any of the coastal samples used in this study may have arisen from an unsampled contributing stock, we employed an assignment test-based approach in the program GENECLASS2 (ver. 2.0; Piry et al., 2004). Specifically, coastal samples were assigned to baseline samples using the Bayesian approach of Rannala and Mountain (1997) and the re-sampling procedure of Paetkau et al. (2004). We employed a probability threshold of $\alpha=0.05$, below which the individual was inferred to have arisen from an unsampled stock. Finally, given that we were unable to sample juvenile individuals from the Hornaday River system, we performed self-assignment tests (following the same computational methods used above) on our Hornaday River baseline to assess the potential for "stays" (Arctic char that were not of Hornaday River origin). 
Mixed-stock fishery analyses were performed using the genetic stock identification program ONCOR (Kalinowski et al., 2007) to estimate the proportional contributions of our baseline sampling locations (i.e., those in Brock and Hornaday River systems) to subsistence fisheries in Darnley Bay. ONCOR, which implements a conditional maximum likelihood approach (Millar, 1987), is reportedly more accurate than other available programs when performing GMA in situations where differentiation among baselines is relatively small (e.g., $\mathrm{F}_{\mathrm{ST}}<0.01$, Araujo et al., 2014). As a first step in evaluating the accuracy of GSI and GMA, given our baselines, we performed simulations of mixtures of fish originating from our baseline sampling locations (i.e., $100 \%$ simulations). In this simulation, a fishery sample is simulated in which all of the individuals are from the baseline sampling location being evaluated (i.e., by randomly drawing allele frequencies calculated from the baseline sample). ONCOR then uses maximum likelihood to estimate the proportion of the simulated fishery sample that is correctly allocated back to the baseline sampling location of origin. Values close to one suggest that the baseline sampling locations should perform well in GSI and GMA, and values over 0.9 are typically considered robust for management applications (Seeb et al., 2000). For this analysis we ran 1000 simulations, sampled 1000 individuals from the fishery, and used the empirical baseline sample sizes (and in this case, the method described by Anderson et al. (2008) to estimate mixture genotypes frequencies), followed by sizes of 100 and 200 to assess the impact of increasing baseline sample sizes (using the reduced-variance estimate method of Kalinowski et al. (2007) to estimate mixture genotypes). Mixture proportions (including 95\% confidence intervals) for each coastal subsistence fishing location and each year sampled (see Table 1) were then estimated by bootstrapping baseline (as per Rannala and Mountain, 1997) and fishery (mixture) samples 1000 times.

\section{RESULTS}

The results of the MICROCHECKER analysis consistently identified three loci potentially exhibiting null alleles or other scoring errors: Sco109, Sco212, and Sco218. Those loci were thus eliminated (along with the monomorphic Smm21) from all subsequent analyses. Thus in total, 987 individuals were collected from eight localities (two of which included coastal mixed-stock fishery sampling locations, Table 1; Fig. 1) and genotyped across 14 microsatellite loci, all of which were polymorphic. Overall genetic variation was relatively high, and descriptive statistics for each sample for each locus are shown in Online Table S2. The number of alleles $\left(\mathrm{N}_{\mathrm{A}}\right)$ per locus ranged from 2 (Sfo18) to 57 (Sco216) and averaged 19.71 across all loci. Expected heterozygosity $\left(\mathrm{H}_{\mathrm{E}}\right)$ ranged from 0.34 (Sfo18) to 0.90 (Sco220) and averaged 0.72 across all loci. Within sample locations, $\mathrm{N}_{\mathrm{A}}$ averaged across all loci ranged from 6.36 in the LAKEB sample to 15.86 in the 2011 Lasard Creek coastal sample
(LAS-11) (Table 2). Allelic richness $\left(A_{R} ; 100\right.$ genes from each sample) averaged across all loci ranged from 6.14 in the LAKE-A sample to 12.29 in the HORN-B sample, and $\mathrm{PA}_{\mathrm{R}}$ ranged from 0.07 in the LAS-12 sample to 0.50 in the 2012 Hornaday coastal sample (HORN-12). Conformation to HWE was not rejected for any sampling location or for any locus. Significant genotypic linkage disequilibrium was detected in 98 of 1184 location-locus-pair comparisons, and only 32 comparisons remained significant after FDR adjustments of alpha (adjusted $\alpha=0.0065$ ).

Log-likelihood (G)-based exact tests of population differentiation suggested that most sampling locations are significantly differentiated from each other $(p<0.05$, Table 3$)$. Fourteen of the 15 comparisons of population pairs were significant both before adjustments of alpha based on the FDR procedure $(p<0.05)$ and afterwards (with adjusted $\alpha$ based on FDR $=0.0151$ ). The only non-significant comparison involved that between the HORN-A and HORN$\mathrm{B}$ baseline sampling locations. Global $\mathrm{F}_{\mathrm{ST}}$ among baseline sampling locations was relatively high $(\theta=0.117 ; 95 \%$ C.I. $=0.097-0.142$ ), and pairwise values of $\mathrm{F}_{\mathrm{ST}}(\theta)$ ranged from virtually no apparent differentiation (between HORN-A and HORN-B) to 0.264 between LAKE-A and LAKE-B (Table 3). Interestingly, all $\mathrm{F}_{\mathrm{ST}}$ comparisons that included the LAKE-A and LAKE-B samples showed noticeably greater differentiation than all other comparisons. This result may relate either to the lack of population connectivity for these samples with our anadromous sampling locations or to unique life history characteristics (i.e., potential freshwater-resident stocks) that exist in these sampling locations. We expand on these potential scenarios below.

We used DAPC to visualize genetic structure among baseline sampling locations, the results of which clearly resolved four genetic clusters (Fig. 2). All LAKE-A samples were assigned to cluster 1, and all LAKE-B samples were assigned to cluster 3 (Fig. 2). Clusters 2 and 4 were clearly admixed with individual Arctic char from both the Brock and Hornaday River baseline samples (Fig. 2). Bayesian clustering implemented in STRUCTURE clearly revealed four genetic groups as the most likely number of clusters (i.e., $\mathrm{K}=4, \Delta \mathrm{K}=114.66$, Online Table S3) following the approach of Evanno et al. (2005). LAKE-A and LAKEB appear clearly divergent, as were BRK-A and BRK-B (Fig. 3). Admixture appeared to be evident among the Hornaday River proper sampling locations (Fig. 3).

Assignment tests implemented in GENCLASS2 confidently assigned the majority of coastal fishery samples to either the Brock or the Hornaday River system. Samples identified as originating from a population not included in the present study (three from the LAS-10 fishery sample and two from the LAS-11 fishery sample, $p<0.05$ ) were removed from the genetic mixed-stock analysis. Additionally, the assignment tests indicated that no coastal sample could confidently be assigned to either the LAKE-A or LAKE-B baseline sampling location (probability of $\sim 0.00$ in all cases). This result, coupled with the elevated levels of genetic differentiation between these sampling locations 
TABLE 2. Basic microsatellite descriptive statistics averaged over all loci for all Arctic char (Salvelinus alpinus) sampling locations assessed in the Darnley Bay region. Shown are the average number of alleles per locus $\left(\mathrm{N}_{\mathrm{A}}\right)$, expected $\left(\mathrm{H}_{\mathrm{E}}\right)$ and observed $\left(\mathrm{H}_{\mathrm{O}}\right)$ heterozygosity, allelic richness $\left(\mathrm{A}_{\mathrm{R}}\right)$, private allelic richness $\left(\mathrm{PA}_{\mathrm{R}}\right)$ and the inbreeding coefficient $\left(\mathrm{F}_{\mathrm{IS}}\right)$. For key to sample codes, see Table 1.

\begin{tabular}{|c|c|c|c|c|c|c|}
\hline BRK-A & 10.14 & 0.73 & 0.71 & 10.14 & 0.18 & 0.03 \\
\hline BRK-B & 8.29 & 0.69 & 0.66 & 8.14 & 0.10 & 0.05 \\
\hline LAKE-B & 6.36 & 0.60 & 0.56 & 6.21 & 0.10 & 0.06 \\
\hline HORN-A & 9.93 & 0.77 & 0.71 & 9.93 & 0.18 & 0.07 \\
\hline HORN-B & 12.29 & 0.77 & 0.73 & 12.29 & 0.24 & 0.06 \\
\hline LAS-10 & 8.14 & 0.73 & 0.66 & 8.14 & 0.32 & 0.10 \\
\hline HORN-09 & 8.71 & 0.74 & 0.71 & 8.71 & 0.14 & 0.04 \\
\hline HORN-10 & 12.07 & 0.76 & 0.69 & 11.84 & 0.38 & 0.09 \\
\hline HORN-11 & 12.86 & 0.75 & 0.74 & 11.53 & 0.27 & 0.02 \\
\hline HORN-12 & 14.14 & 0.75 & 0.70 & 11.64 & 0.50 & 0.07 \\
\hline
\end{tabular}

TABLE 3. Significance of log-likelihood (G)-based exact tests of population differentiation (above diagonal) and pairwise comparisons of $\mathrm{F}_{\mathrm{ST}}(\theta)$ (below diagonal) for Arctic char (Salvelinus alpinus) sampling locations from the Darnley Bay region, Northwest Territories. Values above the diagonal were either non-significant (ns; $p>0.05$ ) or significant $(* * ; p \leq 0.05)$ both before and after adjustments of alpha based on the false discovery rate (FDR) procedure. ${ }^{1}$ With the exception of the pairwise comparison of HORN-A and HORN-B, values below the diagonal were all significant both before and after FDR adjustments of alpha. ${ }^{1}$ For key to sampling location codes, see Table 1 and Figure 1.

\begin{tabular}{|c|c|c|c|c|c|c|}
\hline & BRK-A & BRK-B & LAKE-A & LAKE-B & HORN-A & HORN-B \\
\hline BRK-A & & $* *$ & $* *$ & $* *$ & $* *$ & $* *$ \\
\hline BRK-B & 0.056 & & $* *$ & $* *$ & $* *$ & $* *$ \\
\hline LAKE-A & 0.164 & 0.197 & & $* *$ & $* *$ & $* *$ \\
\hline LAKE-B & 0.162 & 0.204 & 0.264 & & $* *$ & $* *$ \\
\hline HORN-A & 0.010 & 0.040 & 0.159 & 0.159 & & ns \\
\hline HORN-B & 0.010 & 0.035 & 0.146 & 0.142 & 0.001 & \\
\hline
\end{tabular}

${ }^{1}$ Adjusted value: $\alpha=0.0151$.

and the other anadromous baselines, suggests that alternative life history tactics may be present in this system (i.e., they may represent landlocked or freshwater-resident stocks that do not contribute Arctic char to the coastal fishery, see Discussion). Therefore, we also removed LAKE-A and LAKE-B as baselines from the GMA. One individual from the Hornaday River baseline identified as a stray (probability of Hornaday River origin $<0.05$ ) was also subsequently removed from the GMA. Furthermore, given the lack of significant differentiation (as indicated between non-significant $\mathrm{F}_{\mathrm{ST}}$ and genotypic differentiation) between Hornaday River baselines (i.e., 1986 and 2011), these samples were pooled for subsequent GMA (see Waples, 1990). Brock River baselines were not pooled for GMA given the significant genetic structure observed between the baselines from that system.

Overall, the results of the $100 \%$ simulations revealed that our baseline samples have relatively high power for GSI and GMA. Values of more than 0.9 were obtained for the Hornaday River baseline and BRK-B in the $100 \%$ simulations (Online Table S4). The proportion of simulated fishery samples assigned back to the BRK-A sample was 0.731 . Increasing sample sizes slightly increased the proportion of fish assigned back to their baseline sampling location of origin, which suggests that our study would have benefited moderately by including larger baseline sample sizes, and this approach should be considered for future years of study in this system.

Overall, the GMA revealed that Arctic char from both the Brock and Hornaday River systems contribute to the subsistence fisheries in Darnley Bay, although there was some moderate variation in the contributions to the fishery among years and harvest locations (Table 4). In general, however, the harvest was dominated by Arctic char from the Hornaday River system in all study years and locations. For instance, in 2009-12, the Hornaday River annually contributed $83.5 \%, 76.6 \%, 96.4 \%$, and $89.1 \%$ respectively, to the Hornaday River coastal fishery, and in 2010-12, it contributed $50.9 \%, 92.4 \%$. and $77.6 \%$, respectively, to the Lasard Creek coastal fishery (Table 4). It should be noted that the LAS-10 coastal fishery sample was quite small $(\mathrm{N}=19)$; therefore, the contribution of $\sim 51 \%$ from the Hornaday River should be interpreted with caution. Overall, the Brock River baseline sampling location BRK-B contributed the least to both coastal fisheries, with contributions of $5.2 \%$ at Lasard Creek in 2011 and $2.4 \%$ at the Hornaday coastal fishery in 2011. 


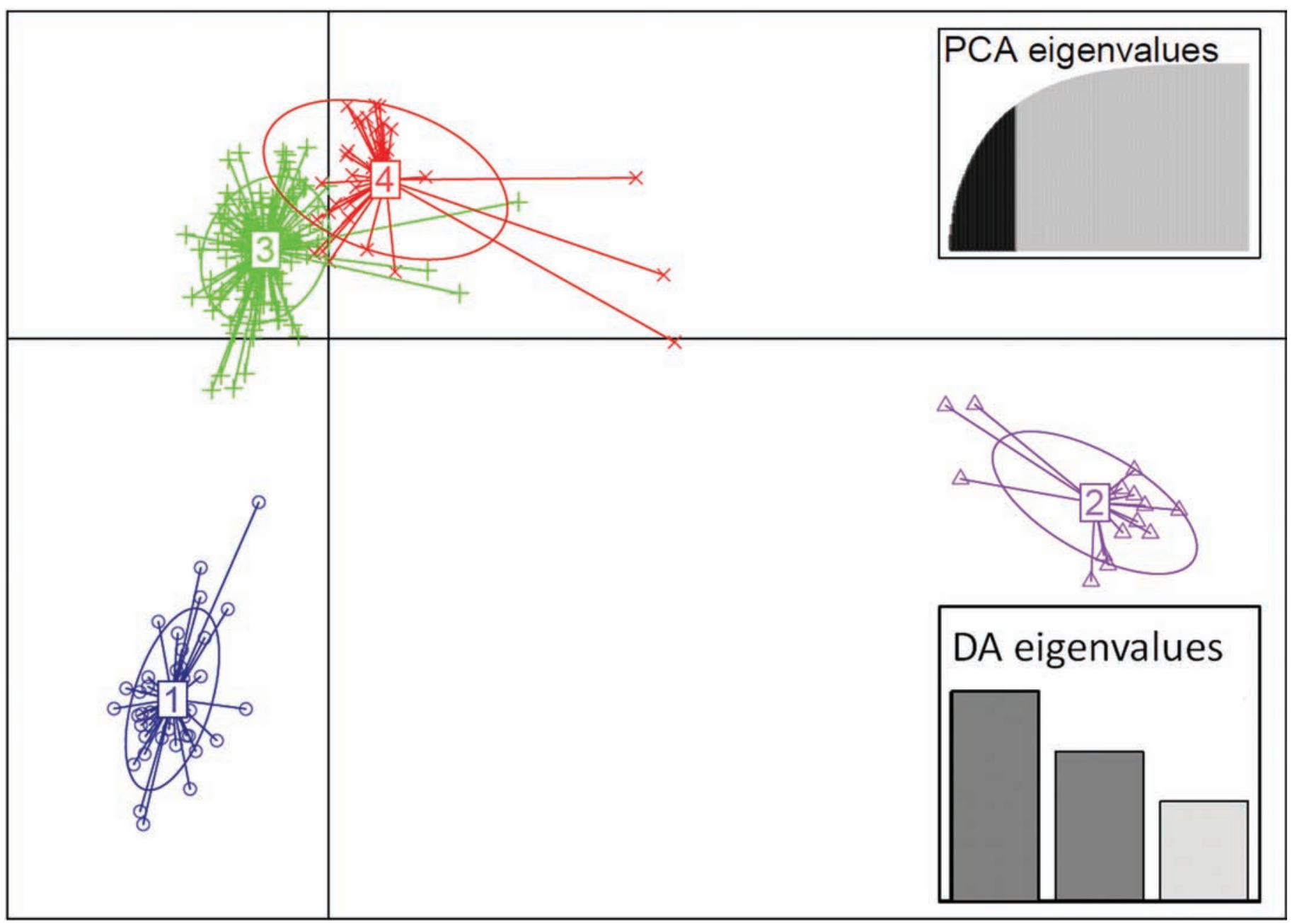

FIG. 2. Scatterplots of the first two principal components of the discriminant analysis of principal components (DAPC) among the baseline sampling locations (i.e., excluding coastal, mixed-stock fishery samples). Sequential K-means clustering identified four groups (i.e., $\mathrm{K}=4$ ) as the most likely number of clusters based on the Bayesian Information Criterion (BIC) for the analysis including only the baseline samples. The scatterplot shows the clustering of individual Arctic char (dots) into the groups represented by the inertia eclipses. Eigenvalues of the analysis are shown in the insets.

\section{DISCUSSION}

Despite the importance of Arctic char to numerous commercial, recreational, and subsistence fisheries in the Canadian Arctic, fine-scale assessments of genetic stock structure in this species are only recently being completed (e.g., Moore et al., 2013; Harris et al., 2014, in press; but see Bernatchez et al., 1998 for an example from the Labrador coast). Our study represents the first assessment of genetic stock structure in Arctic char from the Darnley Bay region of the Northwest Territories, focusing on the two river systems contributing to an important fishery for the community of Paulatuk. Overall, this study revealed significant genetic structure between the baseline sampling locations assessed, similar to that which has been reported in other areas of the Canadian Arctic (Moore et al., 2013; Harris et al., 2014). We did, however, find elevated levels of genetic divergence that were greater than expected on the basis of geographic distance alone (e.g., the $\sim 6 \mathrm{~km}$ fluvial distance between the LAKE-A and LAKE-B samples), which suggests the existence of differing life history

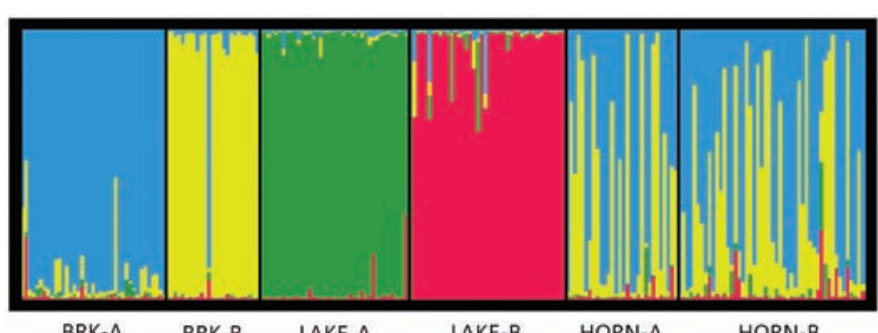

FIG. 3. Results of the Bayesian clustering analysis implemented in STRUCTURE inferred using the $\Delta \mathrm{K}$ statistic of Evanno et al. (2005). The figure shows the proportion of the genome $(\mathrm{Q}$, admixture coefficient) assigned to each inferred cluster $(\mathrm{K})$ when baseline sampling locations were assessed. Each column represents a different individual. The results of clustering are shown in Online Table S3. For key to sampling location codes, see Table 1 and Figure 1.

variants (e.g., landlocked or freshwater-resident) of Arctic char in the Hornaday River system, as discussed below. Finally, we were able to perform GMA on coastal samples using baseline samples from the Hornaday River and Brock River systems, the results of which showed that the 
TABLE 4. Results of the genetic mixed-stock analysis (GMA) generated in ONCOR (Kalinowski et al., 2007), showing the estimated percent annual contributions of source stocks of Arctic char (Salvelinus alpinus) to coastal fisheries at the mouths of the Hornaday River (HORN) and Lasard Creek (LAS) in Darnley Bay, Northwest Territories. The values represent the average estimated percent contributions and the $95 \%$ confidence interval. For key to sampling location codes, see Figure 1 and Table 1.

\begin{tabular}{|c|c|c|c|c|c|c|}
\hline LAS-10 & 0.440 & $(0.115,0.732)$ & 0.052 & $(0.000,0.243)$ & 0.509 & $(0.198,0.829)$ \\
\hline LAS-12 & 0.224 & $(0.080,0.364)$ & 0.002 & $(0.000,0.048)$ & 0.776 & $(0.629,0.911)$ \\
\hline HORN-09 & 0.164 & $(0.000,0.479)$ & 0.001 & $(0.000,0.125)$ & 0.835 & $(0.487,1.000)$ \\
\hline HORN-10 & 0.234 & $(0.066,0.393)$ & 0.005 & $(0.000,0.081)$ & 0.766 & $(0.586,0.917)$ \\
\hline
\end{tabular}

composition of the harvest was slightly variable depending on year and fishing location. Additionally, it became clear that the coastal subsistence fisheries in Darnley Bay, regardless of year or fishing location, primarily harvested Hornaday River Arctic char. This finding is consistent with local traditional knowledge: residents of Paulatuk have long acknowledged that their subsistence fishery is a mixedstock fishery comprising both Brock and Hornaday River fish, but that the harvest is dominated by the latter (Noel Green, Paulatuk resident, pers. comm. 2016). Overall, the results of this study are important to better our understanding of Arctic char biodiversity as it pertains to intra-specific life history variation in Canada's Arctic and to highlight the utility of GMA in identifying contributions to harvest in coastal areas where stocks mix.

\section{Genetic Stock Structure and the Potential for Variant Life Histories}

Understanding diversity in Arctic char as it pertains to life history, as well as historical and contemporary genetic variation, is important for documenting and subsequently monitoring regional biodiversity in a rapidly changing Arctic (Reist et al., 2006, 2013; Schwartz et al., 2007). Our genetic data lend support to the possibility that some sampling locations support Arctic char life history variants that are different from the anadromous forms in the region (see for example MacDonell, 1996, 1997; Babaluk et al., 1998; Reist et al., 1997). Specifically, the degree to which some of our samples are genetically differentiated provides further support (see Babaluk et al., 1998) for the presence of additional life history variants (e.g., freshwater-resident or landlocked Arctic char), in addition to the anadromous life history form, in the Hornaday River drainage. For example, values of $\mathrm{F}_{\mathrm{ST}}$ between our LAKE-A or LAKE-B samples and known anadromous samples ranged from 0.141 to 0.204 , which is magnitudes higher than values in comparisons between known anadromous samples used in this study and in other anadromous stocks of Arctic char from other regions in the Canadian North (Moore et al., 2013; Harris et al., 2014, in press). For example, pairwise estimates of $\mathrm{F}_{\mathrm{ST}}$ among samples of anadromous Arctic char from Cumberland Sound averaged $\sim 0.02-0.04$ (Moore et al., 2013; Harris et al., 2014) and in the Cambridge Bay region of Nunavut, estimates were even lower $(\sim 0.01-0.02$, Harris et al., in press). Additionally Bayesian clustering and DAPC analyses clearly highlight the divergence of the LAKE-A and LAKE-B samples from known anadromous or coastal samples. Thus, the larger-than-expected values of $\mathrm{F}_{\mathrm{ST}}$ in comparisons of LAKE-A or LAKE-B to anadromous samples, coupled with the clear divergence highlighted in our clustering analyses, likely reflect a lack of gene flow between Arctic char in these lakes and the anadromous Hornaday River individuals. This result may be due to the existence of freshwater-resident char that opt to forego marine migrations and are reproductively isolated from their anadromous counterparts or to physical barriers to migration that prevent gene flow between these groups (i.e., LAKE-A and LAKE-B represent landlocked stocks of Arctic char). Indeed, the Arctic char exhibits marked phenotypic, ecological, and life history diversity throughout its range (Klementsen, 2010; Reist et al., 2013) and is arguably the most diverse salmonid (Muir et al., 2015). Further, freshwater-resident Arctic char have been confirmed in the Brock River system through the use of otolith microchemistry (Roux et al., 2011b) and non-anadromous forms are also known in other lakes (e.g., Seven Islands and Rummy Lakes) in the Hornaday River system (McDonnell, 1996, 1997). Indeed, Babaluk et al. (1998) confirmed nonanadromous Arctic char in the Hornaday River system using otolith microchemistry, so the additional life history variation suggested in this study is well aligned with previous observations.

Previous genetic assessments undertaken in the Canadian Arctic (e.g., in Cumberland Sound on Baffin Island) have found non-significant differentiation between freshwater-resident and anadromous forms (Moore et al., 2014), which suggests that the existence of variable forms in some Canadian Arctic systems may indicate conditional mating tactics (one genotype can give rise to two alternative mating tactics, such as residency vs. anadromy; Hendry et al., 2004), rather than the existence of reproductively isolated populations (Moore et al., 2014). Similar results have also been confirmed in the closely related northern Dolly 
Varden (Salvelinus malma malma) where no genetic differences were found between anadromous and freshwater -resident Dolly Varden from the Yukon North Slope (Harris et al., 2015). In our study, we document remarkably high differentiation, thus refuting the hypothesis of conditional mating tactics. Therefore, LAKE-A and LAKE-B Arctic char must be either freshwater life history variants that are reproductively isolated from Hornaday River anadromous Arctic char, even if they do exist in sympatry, or landlocked stocks with no potential for gene flow in and out of these systems. We argue for the latter, given that, to our knowledge, reproductively isolated freshwater and anadromous forms living in sympatry have yet to be documented in the Canadian Arctic, and it is presumed that anadromous Arctic char spawn in the main stem of the Hornaday River (Harwood and Babaluk, 2014). Additionally, many of the tributary lakes in the Hornaday River system are inaccessible to anadromous Arctic char because of steep gradients and minimal or non-existent flows (MacDonell, 1996, 1997). Ground-truthing would be required to confirm that this is also true for LAKE-A and LAKE-B but aerial observations did not lead us to suspect these lakes were inaccessible. Finally, our values of genetic differentiation between the LAKE-A/LAKE-B samples and anadromous samples are consistent with those reported between other landlocked or isolated and anadromous salmonines (Harris et al., 2015; May-McNally et al., 2015). Additional work, however, is required to confirm whether LAKE-A and LAKE$\mathrm{B}$ are truly landlocked stocks that are physically isolated from anadromous Hornaday River Arctic char or whether they are freshwater-resident forms that are reproductively isolated from anadromous char in the region. Documenting and further understanding Arctic char diversity in the region will be important for understanding how char biodiversity is generated and maintained (Reist et al., 2013) while providing baseline information on the distribution of char stocks in the region.

\section{Mixed-stock Analysis of Darnley Bay Arctic Char}

Genetic mixed-stock analysis using GSI has become an important tool for helping fisheries managers understand proportional contributions to harvest in areas where discrete stocks are being exploited simultaneously (e.g., Habicht et al., 2010; Harris and Taylor, 2010; Beacham et al., 2011, 2012; Bradbury et al., 2016). The results of our GMA demonstrate that while both the Brock and the Hornaday River stocks contribute to the Darnley Bay subsistence fishery, overall catches are clearly dominated by fish from the Hornaday River, highlighting the importance of this system. Furthermore, we also found that contributions to harvest varied slightly among harvest locations in Darnley Bay and among years examined. The accuracy of mixture analysis, and assignment tests in general, is influenced by several factors, including the baseline and mixture sample sizes, the number of loci used, the polymorphism of the loci used, and the level of differentiation (i.e., $\mathrm{F}_{\mathrm{ST}}$ ) among sampling locations (Cornuet et al., 1999; Pella and Masuda, 2001; Kalinowski, 2004). Differentiation among baseline samples in the present study was relatively low, and some of our baseline sample sizes were relatively small $(\mathrm{N}<30)$, both of which may have reduced the accuracy of our mixture analysis (e.g., Cornuet et al., 1999). However, the number of loci examined and the variability of these loci should suffice for the accurate estimation of mixture proportions (Cornuet et al., 1999; Kalinowski, 2004). This conclusion, coupled with the results of the $100 \%$ simulations for assessing power, suggests that our results are valid. Additionally, most estimates in our GMA were associated with relatively small standard deviations, which also suggests that our results are accurate.

That the Hornaday River system contributed more fish to the subsistence harvest of Arctic char in Darnley Bay than the Brock system is not overly surprising, for several reasons. The geographic extent of the Hornaday system is much greater than the Brock system (approximately 3:1, respectively), which may translate to substantial differences in population sizes between the two systems. Furthermore, although suitable Arctic char habitat has not been quantified directly in both systems, Roux et al. (2011b) suggest that Brock Lake has low productivity and relatively limited fish habitat potential primarily because of its small size $\left(2.5 \mathrm{~km}^{2}\right)$ and volume $\left(0.02 \mathrm{~km}^{3}\right)$. This situation has implications for Arctic char carrying capacity, and several studies have documented associations between habitat size and population size (Frankham, 1996; Hänfling and Brandl, 1998; Castric et al., 2001). Although abundance estimates are not available for the Brock system, Roux et al. (2011b) suggested, on the basis of low catch-per-unit-effort (CPUE), that the population is likely very small. A test fishery at the Brock River also suggested that Arctic char exist in small numbers in this system (MacDonell, 1988). Alternatively, a conduit weir (i.e., counting fence) operated on the Hornaday River, albeit more than two decades ago, estimated the Arctic char population size in that system to be between 15000 and 16000 individuals (MacDonell, 1986; DFO, 1999). Finally, there is also evidence to suggest that Arctic char captured in the Brock River system may be of Hornaday River origin. For example, results of otolith microchemistry indicate that Hornaday and Brock River anadromous char are strikingly similar in ecology and life history traits (e.g., age-at-first-migration and frequency of migration to sea), which suggests that they could be from the same stock (Roux et al., 2011b). This finding corroborates previous Floy-tagging evidence that documented movement of Arctic char between these two systems (Roux et al., 2011b) and suggests that they do not constitute distinct stocks. More recently, however, radio-telemetry data did not find movement of Arctic char between the Hornaday and Brock systems, although some of the Hornaday-tagged char were captured along the eastern coast of Darnley Bay in the Lasard Creek area (Harwood and Babaluk, 2014), which may also explain the high contributions of Hornaday fish in that area. All told, the results of our GMA point to the 
importance of Hornaday River Arctic char to the subsistence harvest of this species in Darnley Bay, and we suggest this importance is likely due, at least in part, to the greater population size in the Hornaday River stock.

\section{CONSERVATION IMPLICATIONS AND CONCLUSIONS}

To our knowledge, this study represents the first genetic assessment of Arctic char in the region and the first GMA for this species. We documented significant genetic distinction between char stocks located within the two primary river systems adjacent to Darnley Bay-the Hornaday and Brock Rivers - and conclude that both of these stocks contribute to coastal fisheries in the region. Generally, although there was some minor temporal variation in the proportions of stock contributions, the Hornaday River consistently contributed larger proportions of char annually to both proximate and distal fisheries within the bay, highlighting the importance of this river in the region. The results indicate that future management could be designed around the small-scale genetic differences among baseline stocks at the scale of the river system (i.e., Hornaday and Brock Rivers). A similar management technique for Arctic char has been proposed in Cumberland Sound (see Harris et al., 2014). Moreover, Dempson and Kristofferson (1987) have proposed the idea of "local stock complexes," which recognizes that a fishery may be harvesting fish from a number of river systems. In our study area, recognizing Hornaday River and Brock River char as local stock complexes is warranted since they have been identified as genetically discrete stocks, and the composition of the catch from the coastal fishery at different geographic locations has been determined with sufficient power to support GMA. Furthermore, we provide genetic evidence for the existence of additional life history variation that should be further documented through assessment of other freshwater habitats in the region to compile a complete picture of Arctic char biodiversity in Canada's central Arctic. Confirming and documenting additional life history variation, combined with ongoing efforts to resolve stock contributions to Darnley Bay's mixed-stock fishery, will provide important baselines to use when developing management measures and future monitoring programs. Management and monitoring are of paramount importance in regions such as Darnley Bay, where mineral exploration and development can be anticipated (Darnley Bay Resources Limited, 2013; Gavrilchuk and Lesage, 2014). All told, the results of this study should prove important when updating the Paulatuk Charr Management Plan, which is now more than 15 years old.

\section{ACKNOWLEDGEMENTS}

Funding for this study was provided by the Fisheries Joint Management Committee and by Department of Fisheries and Oceans (DFO) Western Arctic Area Office Fisheries and Aquaculture Management Funding. We thank the Paulatuk Hunters and Trappers Committee, the Paulatuk Charr Working Group, Larry Dow (DFO), and Parks Canada for their support of this project. We also thank the harvest monitors for collecting fin clips, J. Reist for access to the 1986 Hornaday River samples, Robert Bajno (DFO) for technical support in the genetics laboratory, and Canadian Helicopters for providing the field sampling flights. Some of the results of this study were recently published as a research document for the Canadian Science Advisory Secretariat (Res Doc 2016/023). This manuscript was greatly improved by comments provided by Karen Dunmall, Lois Harwood, and one anonymous reviewer.

\section{APPENDIX 1}

The following tables are available as a supplementary file to the online version of this article at:

http://arctic.journalhosting.ucalgary.ca/arctic/index.php/ arctic/rt/suppFiles/4578/0

TABLE S1. Polymerase chain reaction (PCR) information. TABLE S2. Basic descriptive statistics for 14 microsatellite loci for the eight Darnley Bay and Hornaday and Brock River Arctic char sampling locations. Average number of alleles per locus $\left(\mathrm{N}_{\mathrm{A}}\right)$, expected $\left(\mathrm{H}_{\mathrm{E}}\right)$ and observed $\left(\mathrm{H}_{\mathrm{O}}\right)$ heterozygosities, inbreeding coefficient $\left(\mathrm{F}_{\mathrm{IS}}\right)$, allelic richness $\left(A_{R}\right)$, and private allelic richness $\left(\mathrm{PA}_{\mathrm{R}}\right)$ are shown for each sampling location for each locus and the averages over all loci. For key to sampling location codes, see Table 1 and Figure 1. $\mathrm{A}_{\mathrm{R}}$ and $\mathrm{PA}_{\mathrm{R}}$ calculated from a sample of 100 genes.

TABLE S3. STRUCTURE (Pritchard et al., 2000) results showing the mean log-likelihood values (LnP[D]) for different hypothesized numbers of genetic populations $(K)$ and the mean value of the $\Delta \mathrm{K}$ statistic of Evanno et al. (2005). Red values represent the most likely number of genetic groups indicated by $\Delta \mathrm{K}$. Dashes $=$ not applicable, given that $\Delta K$ cannot be calculated for these values of $K$. Results of the STRUCTURE analysis are also shown in Figure 3.

TABLE S4. Results of the $100 \%$ simulations performed using the program ONCOR (Kalinowski et al., 2007) to evaluate the power of our baseline sampling locations for genetic stock identification (GSI) and subsequent mixedstock fishery analysis, using empirical baseline sample sizes and simulated sizes of 100 and 200. This analysis creates simulated mixture and baseline samples by randomly drawing allele frequencies from each baseline (i.e., $100 \%$ of the simulated mixture is from one baseline population). ONCOR then estimates the proportion of the simulated mixture sample that is assigned back to the baseline. Values close to 1.0 suggest that the baseline sampling location performs well in GSI, and values greater than 0.9 are suggested to be informative for management purposes. 


\section{REFERENCES}

Anderson, E.C., Waples, R.S., and Kalinowski, S.T. 2008. An improved method for estimating the accuracy of genetic stock identification. Canadian Journal of Fisheries and Aquatic Sciences 65(7):1475-1486.

http://dx.doi.org/10.1139/F08-049

Araujo, H.A., Candy, J.R., Beacham, T.D., White, B., and Wallace, C. 2014. Advantages and challenges of genetic stock identification in fish stocks with low genetic resolution. Transactions of the American Fisheries Society 143(2):479488 . http://dx.doi.org/10.1080/00028487.2013.855258

Babaluk, J., Harwood, L.A., Kristofferson, A., and Reist, J. 1998. Life history and stock differences in Arctic charr of the Paulatuk-Hornaday River, NT area as determined by strontium distribution in otoliths. Prepared for the Fisheries Joint Management Committee, Inuvik, Northwest Territories. Winnipeg: Department of Fisheries and Oceans. 37 p.

Beacham, T.D., McIntosh, B., and Wallace, C.G. 2011. A comparison of polymorphism of genetic markers and population sample sizes required for mixed-stock analysis of sockeye salmon (Oncorhynchus nerka) in British Columbia. Canadian Journal of Fisheries and Aquatic Sciences 68(3):550-562. http://dx.doi.org/10.1139/F10-167

Beacham, T.D., Candy, J.R., Wallace, C., Wetklo, M., Deng, L., and MacConnachie, C. 2012. Microsatellite mixed-stock identification of Coho salmon in British Columbia. Marine and Coastal Fisheries 4(1):85-100.

http://dx.doi.org/10.1080/19425120.2012.661393

Beerli, P. 2004. Effect of unsampled populations on the estimation of population sizes and migration rates between sampled populations. Molecular Ecology 13(4):827-836. http://dx.doi.org/10.1111/j.1365-294X.2004.02101.x

Bernatchez, L., Dempson, J.B., and Martin, S. 1998. Microsatellite gene diversity analysis in anadromous Arctic char, Salvelinus alpinus, from Labrador, Canada. Canadian Journal of Fisheries and Aquatic Sciences 55(5):1264-1272.

http://dx.doi.org/10.1139/f97-325

Bradbury, I.R., Hamilton, L.C., Chaput, G., Robertson, M.J., Goraguer, H., Walsh, A., Morris, V., et al. 2016. Genetic mixed stock analysis of an interceptory Atlantic salmon fishery in the Northwest Atlantic. Fisheries Research 174:234-244. http://dx.doi.org/10.1016/j.fishres.2015.10.009

Brownstein, M.J., Carpten, J.D., and Smith, J.R. 1996. Modulation of non-templated nucleotide addition by Taq DNA polymerase: Primer modifications that facilitate genotyping. BioTechniques 20(6):1004-1010.

Castric, V., Bonney, F., and Bernatchez, L. 2001. Landscape structure and hierarchical genetic diversity in the brook charr, Salvelinus fontinalis. Evolution 55(5):1016-1028. http://dx.doi.org/10.1554/0014-3820(2001)055[1016:LSAHGD ]2.0.CO;2

Cook, R.C., and Guthrie, I. 1987. In-season stock identification of sockeye salmon (Oncorhynchus nerka) using scale pattern recognition. In: Smith, H.D., Margolis, L., and Wood, C.C., eds. Sockeye salmon (Oncorhynchus nerka) population biology and future management. Canadian Special Publication of Fisheries and Aquatic Sciences 96. 327-334.

Cornuet, J.-M., Piry, S., Luikart, G., Estoup, A., and Solignac, M. 1999. New methods employing multilocus genotypes to select or exclude populations as origins of individuals. Genetics 153(4):1989-2000.

Darnley Bay Resources Limited. 2013. Home page. http://www.darnleybay.com/

Dempson, J.B., and Kristofferson, A.H. 1987. Spatial and temporal aspects of the ocean migration of anadromous Arctic char. In: Dadswell, M.J., Klauda, R.J., Moffitt, C.M., Saunders, R.L., Rulifson, R.A., and Cooper, J.E., eds. Common strategies of anadromous and catadromous fishes. Bethesda, Maryland: American Fisheries Society. 340-357.

DFO (Department of Fisheries and Oceans). 1999. Hornaday River Arctic charr. DFO Science Stock Status Report D5-68.

Earl, D.A., and vonHoldt, B.M. 2012. STRUCTURE HARVESTER: A website and program for visualizing STRUCTURE output and implementing the Evanno method. Conservation Genetic Resources 4(2):359-361. http://dx.doi.org/10.1007/s12686-011-9548-7

Evanno, G., Regnaut, S., and Goudet, J. 2005. Detecting the number of clusters of individuals using the software STRUCTURE: A simulation study. Molecular Ecology 14(8):2611-2620. http://dx.doi.org/10.1111/j.1365-294X.2005.02553.x

Excoffier, L., Laval G., and Schneider, S. 2005. Arlequin (version 3.0): An integrated software package for population genetics data analysis. Evolutionary Bioinformatics 1:47-50.

Flannery, B.G., Beacham, T.D., Candy, J.R., Holder, R.R., Maschmann, G.F., Kretschmer, E.J., and Wenburg, J.K. 2010. Mixed-stock analysis of Yukon River chum salmon: Application and validation in a complex fishery. North American Journal of Fisheries Management 30(5):1324-1338. http://dx.doi.org/10.1577/M10-014.1

Frankham, R. 1996. Relationship of genetic variation to population size in wildlife. Conservation Biology 10(6):1500-1508. http://dx.doi.org/10.1046/j.1523-1739.1996.10061500.x

Frantz, A.C., Cellina, S., Krier, A., Schley, L., and Burke, T. 2009. Using spatial Bayesian methods to determine the genetic structure of a continuously distributed population: Clusters or isolation by distance? Journal of Applied Ecology 46(2):493505.

http://dx.doi.org/10.1111/j.1365-2664.2008.01606.x

Friesen, T.M. 2002. Analogues at Iqaluktuuq: The social context of archaeological inference in Nunavut, Arctic Canada. World Archaeology 34(2):330-345. http://dx.doi.org/10.1080/0043824022000007134

___ 2004. Contemporaneity of Dorset and Thule cultures in the North American Arctic: New radiocarbon dates from Victoria Island, Nunavut. Current Anthropology 45(5):685691. http://dx.doi.org/10.1086/425635

Gavrilchuk, K., and Lesage, V. 2014. Large-scale marine development projects (mineral, oil and gas, infrastructure) proposed for Canada's North. Canadian Technical Report of Fisheries and Aquatic Sciences 3069. 84 p. 
Gilbert, C.H. 1924. Experiment in tagging adult red salmon, Alaska Peninsula Fisheries Reservation, summer of 1922. Bulletin of the U.S. Bureau of Fisheries 39:39-50.

Goudet, J. 2002. FSTAT: A program to estimate and test gene diversities and fixation indices. Version 2.9.3.2. www2.unil.ch/popgen/softwares/fstat.htm

Goudet, J., Raymond, M., de Meeüs, T., and Rousset, F. 1996. Testing differentiation in diploid populations. Genetics 144(4):1933-1940.

Habicht, C., Seeb, L.W., Myers, K.W., Farley, E.V., and Seeb, J.E. 2010. Summer-fall distribution of stocks of immature sockeye salmon in the Bering Sea as revealed by single-nucleotide polymorphisms. Transactions of the American Fisheries Society 139(4):1171-1191.

http://dx.doi.org/10.1577/T09-149.1

Hänfling, B., and Brandl, R. 1998. Genetic variability, population size and isolation of distinct populations in the freshwater fish Cottus gobio L. Molecular Ecology 7(12):1625-1632. http://dx.doi.org/10.1046/j.1365-294x.1998.00465.x

Harris, L.N., and Taylor, E.B. 2010. Genetic population structure of broad whitefish, Coregonus nasus, from the Mackenzie River, Northwest Territories: Implications for subsistence fishery management. Canadian Journal of Fisheries and Aquatic Sciences 67(6):905-918.

Harris, L.N., Moore, J.-S., Galpern, P., Tallman, R.F., and Taylor, E.B. 2014. Geographic influences on fine-scale, hierarchical population structure in northern Canadian populations of anadromous Arctic char (Salvelinus alpinus). Environmental Biology of Fishes 97(11):1233-1252. http://dx.doi.org/10.1007/s10641-013-0210-y

Harris, L.N., Bajno, R., Gallagher, C.P., Koizumi, I., Johnson, L.K., Howland, K.L., Taylor, E.B., and Reist, J.D. 2015. Lifehistory characteristics and landscape attributes as drivers of genetic variation, gene flow, and fine-scale population structure in northern Dolly Varden (Salvelinus malma malma) in Canada. Canadian Journal of Fisheries and Aquatic Sciences 72(10):1477-1493.

http://dx.doi.org/10.1139/cjfas-2015-0016

Harris, L.N., Moore, J.-S., Bajno, R., and Tallman, R.F. In press. Genetic population structure of anadromous Arctic char from western Nunavut: Potential implications for the management of Canada's largest Arctic char commercial fishery. North American Journal of Fisheries Management.

Harwood, L.A. 2009. Status of anadromous Arctic charr (Salvelinus alpinus) of the Hornaday River, Northwest Territories, as assessed through harvest-based sampling of the subsistence fishery, August-September 1990-2007. Canadian Manuscript Report of Fisheries and Aquatic Sciences 2890. Yellowknife, Northwest Territories: Fisheries and Oceans Canada. 33 p. http://www.dfo-mpo.gc.ca/Library/338739.pdf

Harwood, L.A., and Babaluk, J.A. 2014. Spawning, overwintering and summer feeding habitats used by anadromous Arctic char (Salvelinus alpinus) of the Hornaday River, Northwest Territories, Canada. Arctic 67(4):449-461.

http://dx.doi.org/10.14430/arctic4422
Hedgecock, D., Banks, M.A., Rashbrook, V.K., Dean, C.A., and Blankenship, S.M. 2001. Applications of population genetics to conservation of chinook salmon diversity in the Central Valley. In: Brown, R.L., ed. Fish Bulletin 179 - Contributions to the Biology of Central Valley salmonids, Vol. 1. Sacramento: Fisheries Branch, California Department of Fish and Wildlife. 45-70.

Hendry, A.P., Castric, V., Kinnison, M.T., and Quinn, T.P. 2004. The evolution of philopatry and dispersal: Homing versus straying in salmonids. In: Hendry, A.P., and Stearns, S.C., eds. Evolution illuminated: Salmon and their relatives. Oxford: Oxford University Press. 52-91.

Jakobsson, M., and Rosenberg, N.A. 2007. CLUMPP: A cluster matching and permutation program for dealing with label switching and multimodality in analysis of population structure. Bioinformatics 23(14):1801-1806.

http://dx.doi.org/10.1093/bioinformatics/btm233

Jombart, T. 2008. adegenet: A R package for the multivariate analysis of genetic markers. Bioinformatics 24(11):1403-1405. http://dx.doi.org/10.1093/bioinformatics/btn129

Jombart, T., Devillard, S., and Balloux, F. 2010. Discriminant analysis of principal components: A new method for the analysis of genetically structured populations. BMC Genetics 11: 94 .

http://dx.doi.org/10.1186/1471-2156-11-94

Kalinowski, S.T. 2004. Genetic polymorphism and mixed-stock fisheries analysis. Canadian Journal of Fisheries and Aquatic Sciences 61(7):1075-1082. http://dx.doi.org/10.1139/f04-060

__ 2005. HP-RARE 1.0: A computer program for performing rarefaction on measures of allelic richness. Molecular Ecology Notes 5(1):187-189. http://dx.doi.org/10.1111/j.1471-8286.2004.00845.x

Kalinowski, S.T., Manlove, K.R., and Taper, M.L. 2007. ONCOR: A computer program for genetic stock identification. Bozeman: Montana State University.

Klemetsen, A. 2010. The charr problem revisited: Exceptional phenotypic plasticity promotes ecological speciation in postglacial lakes. Freshwater Reviews 3(1):49-74.

http://dx.doi.org/10.1608/FRJ-3.1.3

Kristofferson, A.H., and Berkes, F. 2005. Adaptive comanagement of Arctic char in Nunavut Territory. In: Berkes, F., Huebert, R., Fast, H., Manseau, M., and Diduck, A., eds. Breaking ice: Renewable resource and ocean management in the Canadian North. Calgary, Alberta: University of Calgary Press. 249-268.

Kristofferson, A., Lewis, P.N.B., and Gillman, D.V. 1989. Draft Report. Status of the Arctic charr stock of the Hornaday River, Northwest Territories, 1973-1986. Central and Arctic Region, Dept. of Fisheries and Oceans, 501 University Crescent, Winnipeg, Manitoba R3T 2N6.

Krueger, C.C., Wilmot, R.L., and Everett, R.J. 1999. Stock origins of Dolly Varden collected from Beaufort Sea coastal sites of Arctic Alaska and Canada. Transactions of the American Fisheries Society 128(1):49-57.

http://dx.doi.org/10.1577/1548-8659(1999)128\%3C0049:SOO DVC\%3E2.0.CO;2 
MacDonell, D.S. 1986. Report on the enumeration of the 1986 upstream migration of Arctic charr in the Hornaday River, NWT and the evaluation of a weir as a method of capturing fish for commercial harvest. Winnipeg, Manitoba: North/South Consultants Inc., for Fisheries Joint Management Committee, Box 2120, Inuvik, Northwest Territories X0E 0T0, and the Department of Fisheries and Oceans, Winnipeg, Manitoba R3T 2N6. 42 p.

_ _ 1988. Report on the test fisheries conducted at the Hornaday, Brock and Horton Rivers in 1987-1988, and an evaluation of the Arctic char fishery at Paulatuk, N.W.T. Winnipeg, Manitoba: North/South Consultants Inc., for Fisheries Joint Management Committee, Box 2120, Inuvik, Northwest Territories X0E 0T0.

- 1996. Hornaday River - Paulatuk, NWT Arctic charr spawning location study. Winnipeg, Manitoba: North/South Consultants Inc. 21 p. Available from Fisheries and Oceans Canada, 301, 5204-50th Avenue, Yellowknife, Northwest Territories X1A 1E2.

___ 1997. Hornaday River - Paulatuk, NWT Arctic charr spawning location study: August-September 1997. Winnipeg, Manitoba: North/South Consultants Inc. 25 p. Available from Fisheries and Oceans Canada, 301, 5204-50th Avenue, Yellowknife, Northwest Territories, X1A 1E2.

Manel, S., Gaggiotti, O.E., and Waples, R.S. 2005. Assignment methods: Matching biological questions with appropriate techniques. Trends in Evolution \& Ecology 20(3):136-142.

http://dx.doi.org/10.1016/j.tree.2004.12.004

Margolis, L. 1963. Parasites as indicators of the geographical origin of sockeye salmon, Oncorhynchus nerka (Walbaum), occurring in the North Pacific Ocean and adjacent seas. International North Pacific Fisheries Commission Bulletin 11:101-156.

May-McNally, S.L., Quinn, T.P., Woods, P.J., and Taylor, E.B. 2015. Evidence for genetic distinction among sympatric ecotypes of Arctic char (Salvelinus alpinus) in south-western Alaskan lakes. Ecology of Freshwater Fish 24(4):562-574. http://dx.doi.org/10.1111/eff.12169

Millar, R.B. 1987. Maximum likelihood estimation of mixed stock fishery composition. Canadian Journal of Fisheries and Aquatic Sciences 44(3):583-590.

http://dx.doi.org/10.1139/f87-071

Moore, J.-S., Harris, L.N., Tallman, R.F., and Taylor, E.B. 2013. The interplay between dispersal and gene flow in anadromous Arctic char (Salvelinus alpinus): Implications for potential for local adaptation. Canadian Journal of Fisheries and Aquatic Sciences 70(9):1327-1338.

http://dx.doi.org/10.1139/cjfas-2013-0138

Moore, J.-S., Loewen, T.N., Harris, L.N., and Tallman, R.F. 2014. Genetic analysis of sympatric migratory ecotypes of Arctic charr Salvelinus alpinus: Alternative mating tactics or reproductively isolated strategies? Journal of Fish Biology 84(1):145-162.

http://dx.doi.org/10.1111/jfb.12262
Muir, A.M., Hansen, M.J., Bronte, C.R., and Krueger, C.C. 2015. If Arctic charr Salvelinus alpinus is 'the most diverse vertebrate', what is the lake charr Salvelinus namaycush? Fish and Fisheries: Early View.

http://dx.doi.org/10.1111/faf.12114

Narum, S.R. 2006. Beyond Bonferroni: Less conservative analyses for conservation genetics. Conservation Genetics 7(5):783-787. http://dx.doi.org/10.1007/s10592-005-9056-y

Paetkau, D., Slade, R., Burden, M., and Estoup, A. 2004. Genetic assignment methods for the direct, real-time estimation of migration rate: A simulation-based exploration of accuracy and power. Molecular Ecology 13(1):55-65. http://dx.doi.org/10.1046/j.1365-294X.2004.02008.x

Pella, J., and Masuda, M. 2001. Bayesian methods for analysis of stock mixtures. Fisheries Bulletin 99:151-167.

PHTC (Paulatuk Hunters and Trappers Committee). 1999. Paulatuk Charr Management Plan 1998-2002. Prepared by Paulatuk Charr Working Group, Paulatuk, NT. Signed at Paulatuk, Northwest Territories, Canada, on 8 July 1998. Available from: Department of Fisheries and Oceans, Box 1871, Inuvik, Northwest Territories X0E 0T0.

Piry, S., Alapetite, A., Cornuet, J.-M., Paetkau, D., Baudouin, L., and Estoup, A. 2004. GENECLASS2: A software for genetic assignment and first-generation migrant detection. Journal of Heredity 95(6):536-539. http://dx.doi.org/10.1093/jhered/esh074

Priest, H., and Usher, P.J. 2004. The Nunavut wildlife harvest study: Final report. Iqaluit: Nunavut Wildlife Management Board.

Pritchard, J.K., Stephens, M., and Donnelly, P. 2000. Inference of population structure using multilocus genotype data. Genetics 155(2):945-959.

R Development Core Team. 2010. R: A language and environment for statistical computing. Vienna: R Foundation for Statistical Computing.

Rannala, B., and Mountain, J.L. 1997. Detecting immigration by using multilocus genotypes. Proceedings of the National Academy of Sciences 94(17):9197-9201.

Reist, J.D., Johnson, J.D., and Carmichael, T.J. 1997. Variation and specific identity of char from northwestern Arctic Canada and Alaska. In: Reynolds, J.B., ed. Fish ecology in Arctic North America. American Fisheries Society Symposium 19. 250-261.

Reist, J.D., Wrona, F.J., Prowse, T.D., Power, M., Dempson, J.B., King, J.R., and Beamish, R.J. 2006. An overview of effects of climate change on selected Arctic freshwater and anadromous fishes. Ambio 35(7):381-387. http://dx.doi.org/10.1579/0044-7447(2006)35[381:AOOEOC]2 $.0 . \mathrm{CO} ; 2$

Reist, J.D., Power, M., and Dempson, J.B. 2013. Arctic charr (Salvelinus alpinus): A case study of the importance of understanding biodiversity and taxonomic issues in northern fishes. Biodiversity 14(1):45-56.

http://dx.doi.org/10.1080/14888386.2012.725338 
Rosenberg, N.A. 2004. DISTRUCT: A program for the graphical display of population structure. Molecular Ecology Notes 4(1):137-138. http://dx.doi.org/10.1046/j.1471-8286.2003.00566.x

Rousset, F. 2008. GENEPOP'007: A complete re-implementation of the GENEPOP software for Windows and Linux. Molecular Ecology Resources 8(1):103-106. http://dx.doi.org/10.1111/j.1471-8286.2007.01931.x

Roux, M.-J., Tallman, R.F., and Lewis, C.W. 2011a. Small-scale Arctic charr Salvelinus alpinus fisheries in Canada's Nunavut: Management challenges and options. Journal of Fish Biology 79(6):1625-1647. http://dx.doi.org/10.1111/j.1095-8649.2011.03092.x

Roux, M.-J., Harwood, L.A., Illasiak, J., Babaluk, J.A., and de Graff, N. 2011b. Fishery resources and habitats in a headwater lake of the Brock River, NT, 2003-2005. Canadian Manuscript Report of Fisheries and Aquatic Sciences 2932. 61 p. http://www.dfo-mpo.gc.ca/Library/346970.pdf

Ruzzante, D.E., Taggart, C.T., Lang, S., and Cook, D. 2000. Mixedstock analysis of Atlantic cod near the Gulf of St. Lawrence based on microsatellite DNA. Ecological Applications 10(4):1090-1109.

http://dx.doi.org/10.1890/1051-0761(2000)010\%5B1090:MSA OAC \%5D2.0.CO;2

Schwartz, M.K., Luikart, G., and Waples, R.S. 2007. Genetic monitoring as a promising tool for conservation and management. Trends in Ecology \& Evolution 22(1):25-33. http://dx.doi.org/10.1016/j.tree.2006.08.009

Seeb, L.W., and Crane, P.A. 1999. Allozymes and mitochondrial DNA discriminate Asian and North American populations of chum salmon in mixed-stock fisheries along the south coast of the Alaska Peninsula. Transactions of the American Fisheries Society 128(1):88-103.

http://dx.doi.org/10.1577/1548-8659(1999)128\%3C0088:AAM DDA\%3E2.0.CO;2

Seeb, L.W., Habicht, C., Templin, W.D., Tarbox, K.E., Davis, R.Z., Brannian, L.K., and Seeb, J.E. 2000. Genetic diversity of sockeye salmon of Cook Inlet, Alaska, and its application to management of populations affected by the Exxon Valdez oil spill. Transactions of the American Fisheries Society 129(6):1223-1249.
Small, M.P., Rogers Olive, S.D., Seeb, L.W., Seeb, J.E., Pascal, C.E., Warheit, K.I., and Templin, W. 2015. Chum salmon genetic diversity in the northeastern Pacific Ocean assessed with single nucleotide polymorphisms (SNPs): Applications to fishery management. North American Journal of Fisheries Management 35(5):974-987. http://dx.doi.org/10.1080/02755947.2015.1055014

Utter, F., and Ryman, N. 1993. Genetic markers and mixed stock fisheries. Fisheries 18(8):11-21.

http://dx.doi.org/10.1577/1548-8446(1993)018<0011:GMAMS $\mathrm{F}>2.0 . \mathrm{CO} ; 2$

Van Oosterhout, C., Hutchinson, W.F., Wills, D.P.M., and Shipley, P. 2004. MICRO-CHECKER: Software for identifying and correcting genotyping errors in microsatellite data. Molecular Ecology Notes 4(3):535-538. http://dx.doi.org/10.1111/j.1471-8286.2004.00684.x

Wang, J., and Santure, A.W. 2009. Parentage and sibship inference from multilocus genotype data under polygamy. Genetics 181(4):1579-1594. http://dx.doi.org/10.1534/genetics.108.100214

Waples, R.S. 1990. Temporal changes of allele frequency in Pacific salmon: Implications for mixed-stock fishery analysis. Canadian Journal of Fisheries and Aquatic Sciences 47(5):968976.

http://dx.doi.org/10.1139/f90-111

1998. Separating the wheat from the chaff: Patterns of genetic differentiation in high gene flow species. Journal of Heredity 89(5):438-450. http://dx.doi.org/10.1093/jhered/89.5.438

Waples, R.S., and Gaggiotti, O. 2006. What is a population? An empirical evaluation of some genetic methods for identifying the number of gene pools and their degree of connectivity. Molecular Ecology 15(6):1419-1439. http://dx.doi.org/10.1111/j.1365-294X.2006.02890.x

Weir, B.S., and Cockerham, C.C. 1984. Estimating $F$-statistics for the analysis of population structure. Evolution 38(6):13581370 .

http://dx.doi.org/10.2307/2408641

Zeller, D., Booth, S., Pakhomov, E., Swartz, W., and Pauly, D. 2011. Arctic fisheries catches in Russia, USA, and Canada: Baselines for neglected ecosystems. Polar Biology 34(7):955973.

http://dx.doi.org/10.1007/s00300-010-0952-3 